OPEN ACCESS

Edited by:

David H. Volle,

INSERM, France

Reviewed by:

Sylvie Babajko,

Centre de Recherche des Cordeliers,

France

Ren-Shan Ge,

Wenzhou Medical University, China

*Correspondence:

Bruce A. Bunnell

bbunnel/@tulane.edu

Specialty section:

This article was submitted to

Cellular Endocrinology,

a section of the journal

Frontiers in Endocrinology

Received: 23 August 2016 Accepted: 19 December 2016

Published: 09 January 2017

Citation:

Bateman ME, Strong AL, McLachlan JA, Burow ME and Bunnell BA (2017) The Effects of

Endocrine Disruptors on Adipogenesis and Osteogenesis in Mesenchymal Stem Cells: A Review.

Front. Endocrinol. 7:171.

doi: 10.3389/fendo.2016.00171

\section{The Effects of Endocrine Disruptors on Adipogenesis and Osteogenesis in Mesenchymal Stem Cells: A Review}

\author{
Marjorie E. Bateman', Amy L. Strong', John A. McLachlan², Matthew E. Burow ${ }^{3}$ and \\ Bruce A. Bunnell ${ }^{1,2 *}$ \\ ${ }^{1}$ Center for Stem Cell Research and Regenerative Medicine, Tulane University School of Medicine, New Orleans, LA, USA, \\ ${ }^{2}$ Department of Pharmacology, Tulane University School of Medicine, New Orleans, LA, USA, ${ }^{3}$ Department of Medicine, \\ Tulane University School of Medicine, New Orleans, LA, USA
}

Endocrine-disrupting chemicals (EDCs) are prevalent in the environment, and epidemiologic studies have suggested that human exposure is linked to chronic diseases, such as obesity and diabetes. In vitro experiments have further demonstrated that EDCs promote changes in mesenchymal stem cells (MSCs), leading to increases in adipogenic differentiation, decreases in osteogenic differentiation, activation of pro-inflammatory cytokines, increases in oxidative stress, and epigenetic changes. Studies have also shown alteration in trophic factor production, differentiation ability, and immunomodulatory capacity of MSCs, which have significant implications to the current studies exploring MSCs for tissue engineering and regenerative medicine applications and the treatment of inflammatory conditions. Thus, the consideration of the effects of EDCs on MSCs is vital when determining potential therapeutic uses of MSCs, as increased exposure to EDCs may cause MSCs to be less effective therapeutically. This review focuses on the adipogenic and osteogenic differentiation effects of EDCs as these are most relevant to the therapeutic uses of MSCs in tissue engineering, regenerative medicine, and inflammatory conditions. This review will highlight the effects of EDCs, including organophosphates, plasticizers, industrial surfactants, coolants, and lubricants, on MSC biology.

Keywords: endocrine disruptors, mesenchymal stem cells, adipogenesis, tissue engineering, tissue scaffolds, immunomodulation

\footnotetext{
Abbreviations: ALP, alkaline phosphatase; aP2, adipocyte protein 2; BBP, benzyl butyl phthalate; BMP, bone morphogenetic protein; BPA, bisphenol A; C/EBP, CCAAT/enhancer-binding protein; DBP, dibutyl phthalate; DCHP, dicyclohexyl phthalate; DDE, dichlorodiphenyldichloroethylene or 1,1-dichloro-2,2-bis (p-chlorophenyl)-ethylene; DDT, dichlorodiphenyltrichloroethane or 1,1,1-trichloro-2,2-bis (p-chlorophenyl)-ethane; DEHP, di-(2-ethyl hexyl)phthalate; DEP, diethyl phthalate; EAE, experimental autoimmune encephalomyelitis; EDC, endocrine-disrupting chemical; ER, estrogen receptor; GR, glucocorticoid receptor; IL-10, interleukin 10; MBP, mono-butyl phthalate; MBzP, mono-benzyl phthalate; MEHP, mono-(2-ethylhexyl) phthalate; miRNA, microRNA; MSC, mesenchymal stem cell; NMDRC, non-monotonic dose-response curve; NOS, nitric oxide synthase; NP, nonylphenol; OP, octylphenol; PPAR $\gamma$, peroxisome proliferator-activated receptor gamma; PCB, polychlorinated biphenyl; ROS, reactive oxygen species; SREBF, sterol regulatory element binding factor; TGF- $\beta$, transforming growth factor beta; TNF- $\alpha$, tumor necrosis factor alpha.
} 


\section{MESENCHYMAL STEM CELLS (MSCs)}

Mesenchymal stem cells are multipotent cells that maintain homeostasis in the human body by regeneration and repair of damaged and aged tissues. According to the International Society for Cellular Therapy, MSCs are cells that adhere to plastic in standard culture conditions, express surface antigens CD105, CD73, and CD90, lack hematopoietic antigens CD45, CD34, CD14 or CD11b, CD79alpha or CD19, and HLA-DR, and differentiate into chondroblasts, myoblasts, osteoblasts, adipocytes, fibroblasts, and stromal cells (1). Figure 1 depicts MSC differentiation into these lineages. An additional characteristic of MSCs is high self-renewal capacity, allowing these cells to retain their undifferentiated phenotype through senescence or until differentiation is induced (2). MSCs have been isolated from various tissues, including bone marrow, adipose tissue, periosteum, muscle tissue, blood vessels, lymphoid organs, skin, lung, umbilical cord blood, Wharton's jelly, placenta, amniotic fluid, and fetal tissue (3-6).

With regard to tissue regeneration and repair, MSCs act by direct differentiation and paracrine signaling effects (4, 7-9). Under the appropriate stimuli, MSCs can differentiate into more specialized cells. Paracrine signaling effects of MSCs recruit other host cells and secrete growth factors and proteins to further stimulate regeneration to replace damaged cells (8). The woundhealing capacity of MSCs has led to studies in tissue engineering and regenerative medicine, such as seeding MSCs onto scaffolds to repair critical-sized bony defects (10). Scaffolds provide a three-dimensional structure to mechanically stimulate MSCs to undergo osteogenic differentiation or to secrete paracrine factors (10-13). Together, these studies suggest that MSCs may have potential applications in the repair of fractures and bony defects (10-13).

Mesenchymal stem cells have also been shown to reduce inflammation and have sparked significant interest due to their potential use in immunotherapy. Specifically, MSCs suppress T-cell proliferation and cytotoxic potential, inhibit maturation and T-cell stimulation by dendritic cells, inhibit B-cell proliferation and differentiation, reduce production of pro-inflammatory cytokines, such as tumor necrosis factor alpha (TNF- $\alpha$ ), and enhance production of anti-inflammatory cytokines, such as interleukin 10 (IL-10) and interleukin 4 (8, 9, 14-18). These effects are mediated by release of immunomodulatory factors such as nitric oxide synthase (NOS), indoleamine 2,3-dioxygenase, prostaglandin E2, and IL-10 in MSCs (18). MSCs are capable of prolonging survival of allografts, reducing acute graft-versus-host

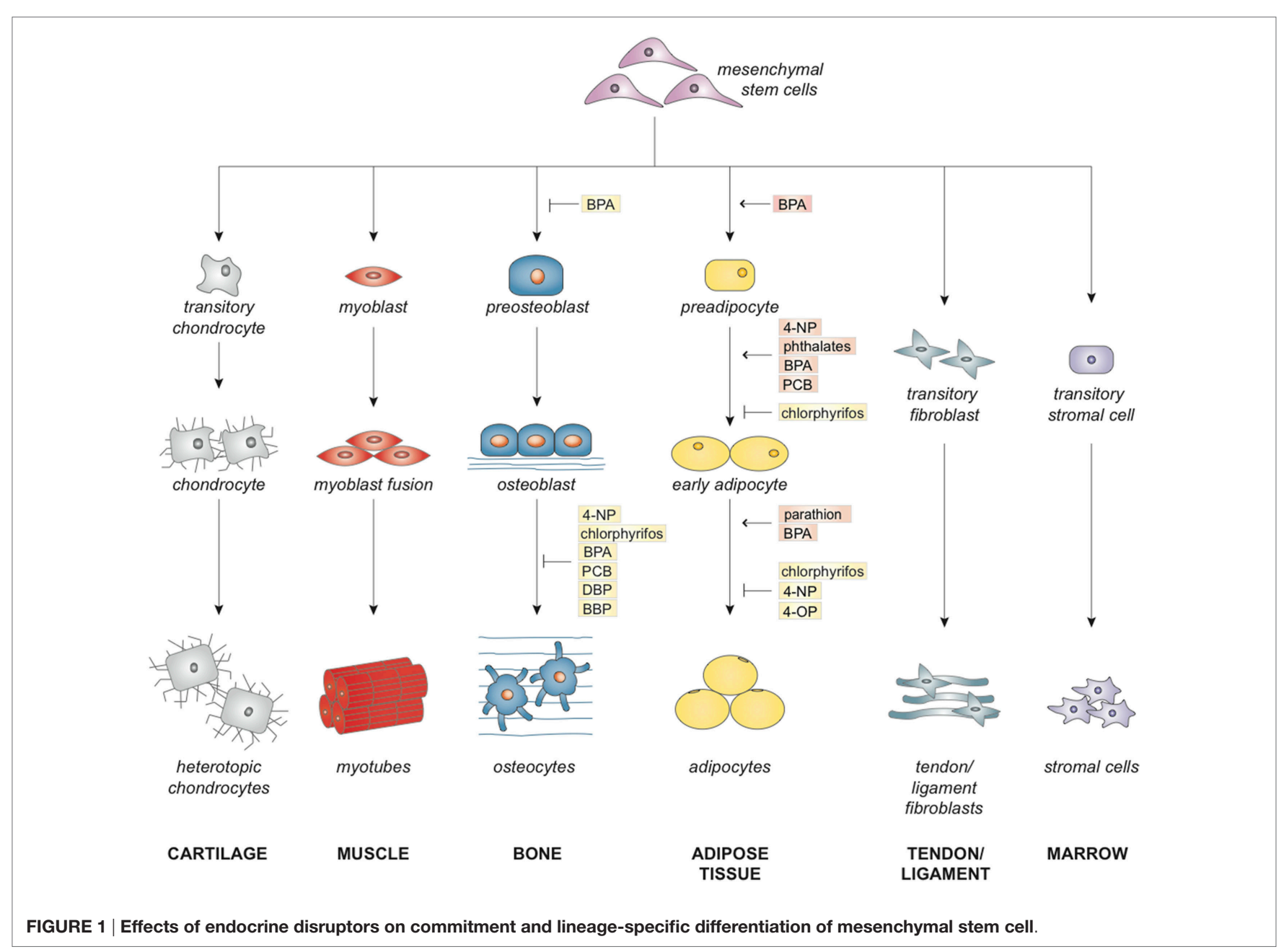


disease, and improving outcomes in experimental autoimmune encephalomyelitis (15-19). Thus, MSCs may have broad therapeutic uses in the prevention and treatment of diseases with pro-inflammatory pathogenesis.

\section{ENDOCRINE DISRUPTORS}

Endocrine-disrupting chemicals (EDCs) are environmental substances that alter the function of the endocrine system, producing adverse health effects in exposed organisms and their offspring (20). EDCs have been shown to have a variety of effects on MSCs. Recent studies gleaned from other cell types have also provided insight into the effects of EDCs on MSCs. These effects of EDCs may alter the therapeutic efficacy of MSCs and thus should be further elucidated.

\section{EFFECT OF ENDOCRINE DISRUPTORS ON MSCs AND MSC LINEAGES}

Low concentrations of several EDCs have been found in various human tissues. While these concentrations are as low as $100 \mathrm{pM}$ to $1 \mathrm{nM}$, EDCs have been demonstrated to exert effects at these concentrations (21-23). Structural similarities between these EDCs and endogenous hormones indicate that the ability of EDCs to affect homeostasis may be through activation of hormone receptors. Like hormones, EDCs are able to function at very low doses in a tissue-specific manner, which is consistent with EDCs having non-monotonic dose-response curves (21-24). Therefore, the presence of low levels in human subjects does not indicate lack of harm from EDC exposure (21-23). At these levels, studies have shown that EDCs induce adipogenesis, increase oxidative stress, promote a pro-inflammatory state, and produce epigenetic changes (22). Low levels of EDCs have been shown to induce adipogenesis, increase oxidative stress, promote a pro-inflammatory state, and produce epigenetic changes. These effects are depicted in Figure 2.

\section{ADIPOGENESIS}

Adipogenesis is the differentiation of preadipocytes into adipocytes and is important for storage of lipids and metabolism in the human body. Adipogenesis requires a supportive environment and a peroxisome proliferator-activated receptor gamma $(\operatorname{PPAR} \gamma)$ ligand (25). In order to support adipogenic differentiation, the appropriate cell density, spatial cell distribution, extracellular matrix, and a soluble hormonal stimulus, such as insulin-like growth factor 1 receptor, glucocorticoid receptor (GR), or cyclic adenosine monophosphate-dependent protein kinase must be present. As the master regulator of adipogenesis both in vitro and in vivo, PPAR $\gamma$ has been demonstrated to be necessary and solely sufficient for adipogenic differentiation to occur in a supportive environment $(21,26,27)$. PPAR $\gamma$ expression, induced by CCAAT/enhancer-binding protein (C/EBP) $\beta$ and $\delta$, engages in a feed-forward loop with $\mathrm{C} / \mathrm{EBP} \alpha$ to promote adipogenesis $(21,26)$.

Endocrine-disrupting chemical exposure in utero and after birth has been linked to increased adipogenesis and the obesity epidemic. During development in utero and in the first few years of life, children are exposed to EDCs that can induce changes in stem cells during periods of differentiation and alter developmental programing of metabolism $(21,25,28)$. These changes induced in MSCs, including epigenetic alterations, may predispose MSCs to undergo adipogenesis, leading to obesity later in life $(25,29-31)$. Continued lifelong exposure to EDCs may further exacerbate the situation by promoting adipogenesis and altering metabolism in a population already susceptible to obesity (32). In vivo studies of the effects of endocrine disruptors have confirmed the findings of in vitro studies. Studies in rats and mice have demonstrated increased body weight and visceral adiposity in animals exposed to EDCs (33-37). Perinatal and prenatal exposures have also been shown to result in excessive weight gain and adipose tissue mass in offspring (30, 31, 38-47). Human studies have demonstrated a positive association between EDC exposures and obesity, increased weight circumference, or increased body mass index $(28,30,40,42,48-65)$.

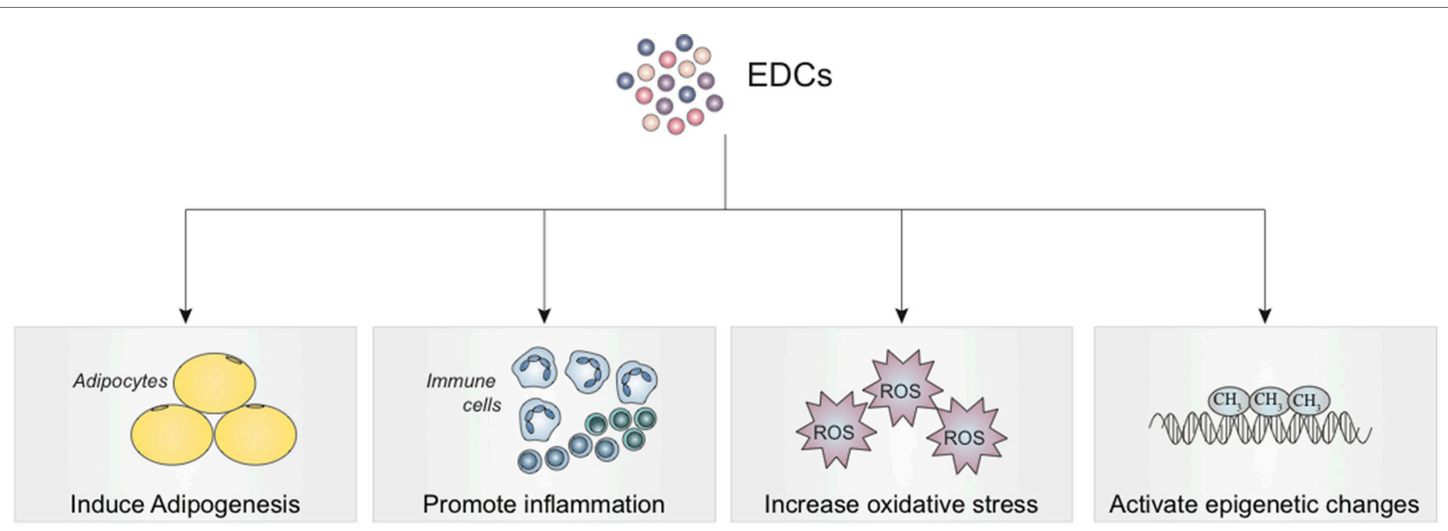

FIGURE 2 | Effects of endocrine-disrupting chemical exposure on mesenchymal stem cells with implications for tissue engineering, regenerative medicine, and treatment of inflammatory conditions. 
The precise mechanism by which EDCs promote adipogenesis has been linked to PPAR $\gamma$ and promotion of a supportive environment for adipogenesis. Several EDCs have been shown to upregulate MSC and preadipocyte differentiation into adipocytes at concentrations ranging from $100 \mathrm{pM}$ to $100 \mu \mathrm{M}$ : dichlorodiphenyltrichloroethane or 1,1,1-trichloro-2,2-bis ( $p$-chlorophenyl)ethane (DDT), 4-nonylphenol (4-NP), octylphenol (OP), bisphenol A (BPA), polychlorinated biphenyl (PCB)-77, PCB101, PCB-153, PCB-180, di-(2-ethyl hexyl)phthalate (DEHP), mono-(2-ethylhexyl)phthalate (MEHP), dibutyl phthalate (DBP), benzyl butyl phthalate (BBP), dicyclohexyl phthalate (DCHP), and mono-benzyl phthalate (MBzP) (30, 35, 37, 39, 40, 42, 43, 46, 63, 66-80). Many endocrine disruptors target PPAR $\gamma$ by binding to it directly to activate downstream cascades that lead to enhanced adipogenesis or by increasing PPAR $\gamma$ expression to allow for a lower threshold for activation. These EDCs include DDT, dichlorodiphenyldichloroethylene or 1,1-dichloro-2,2-bis (p-chlorophenyl)-ethylene (81), 4-NP, OP, BPA, PCB-77, DEHP, MEHP, DBP, BBP, and MBzP $(35,37,39,43,63,66,68-70$, $75,77-80,82-85)$. Perinatal exposure to 4 -NP has also been shown to increase PPAR $\gamma$ gene expression and sterol regulatory element-binding factor 1 (SREBF-1) expression in adipose tissue (83). SREBF-1 is a key transcriptional activator involved in adipogenesis and transcription of PPARG, the gene encoding PPAR $\gamma$. BPA has been shown to directly upregulate SREBF1. BPA has also been shown to upregulate mammalian target of rapamycin pathways in human preadipocytes, and the activation of this pathway through phosphoinositol-3 kinase/Akt leads to the activation of PPAR $\gamma$ and SREBF-1 $(85,86)$. Thus, PPAR $\gamma$ and SREBF-1 are key transcriptional factors in adipogenesis. The expression of $\mathrm{C} / \mathrm{EBP} \alpha$ and expression of factors promoted by
PPAR $\gamma$, such as lipoprotein lipase and fatty acid binding protein 4/adipocyte protein 2 ( $\mathrm{aP} 2$ ), have been shown to be increased in response to DDT, DDE, 4-NP, BPA, PCB-77, DEHP, MEHP, and BBP $(37,39,42,45,46,66,68,69,73,75,76,78,82-84,86-89)$. $p, p^{\prime}$-DDT has also been shown to increase binding of $\mathrm{C} / \mathrm{EBP} \alpha$ to its DNA response element, demonstrating that the promotion of adipogenesis may be occurring through both increased expression and activation of targeted receptors (66).

In order to promote a supportive environment for adipogenesis, studies have also shown that $100 \mathrm{pM}$ to $1 \mu \mathrm{M}$ of EDCs, such as BPA and DCHP, may directly or indirectly cause increased interaction with the GR. BPA and DCHP have been shown to act through the GR to increase lipid accumulation and adipogenesis $(34,67,71)$. BPA also has GR-mediated indirect effects by increasing mRNA expression and enzymatic activity of 11betahydroxysteroid dehydrogenase 1 . This enzyme converts cortisone to cortisol, which can bind the GR in adipose tissue and promote adipogenesis (46).

In addition to PPAR $\gamma$ - and GR-mediated pathways, EDCs have been shown to enhance adipogenesis through other pathways. Paradoxically, $100 \mathrm{nM}$ to $10 \mu \mathrm{M}$ concentrations of DDT and BPA have the capacity to enhance adipogenesis by estrogen receptor (ER)-mediated signaling, which has classically been shown to inhibit adipogenesis $(68,69,90-93)$. Biasiotto and colleagues addressed the issue of multiple endocrine disruptors simultaneously acting on MSCs in the environment (Figure 3). This study demonstrated that the combination of endocrine disruptors such as BPA and NP present at concentrations of 40 and $90 \mathrm{nM}$ in wastewater may promote adipogenesis through ER-mediated pathways. Pure BPA at 50 and $80 \mu \mathrm{M}$ also induced adipogenesis in this study (35). At 25 and $50 \mu \mathrm{M}$ of BPA, induction of aP2,

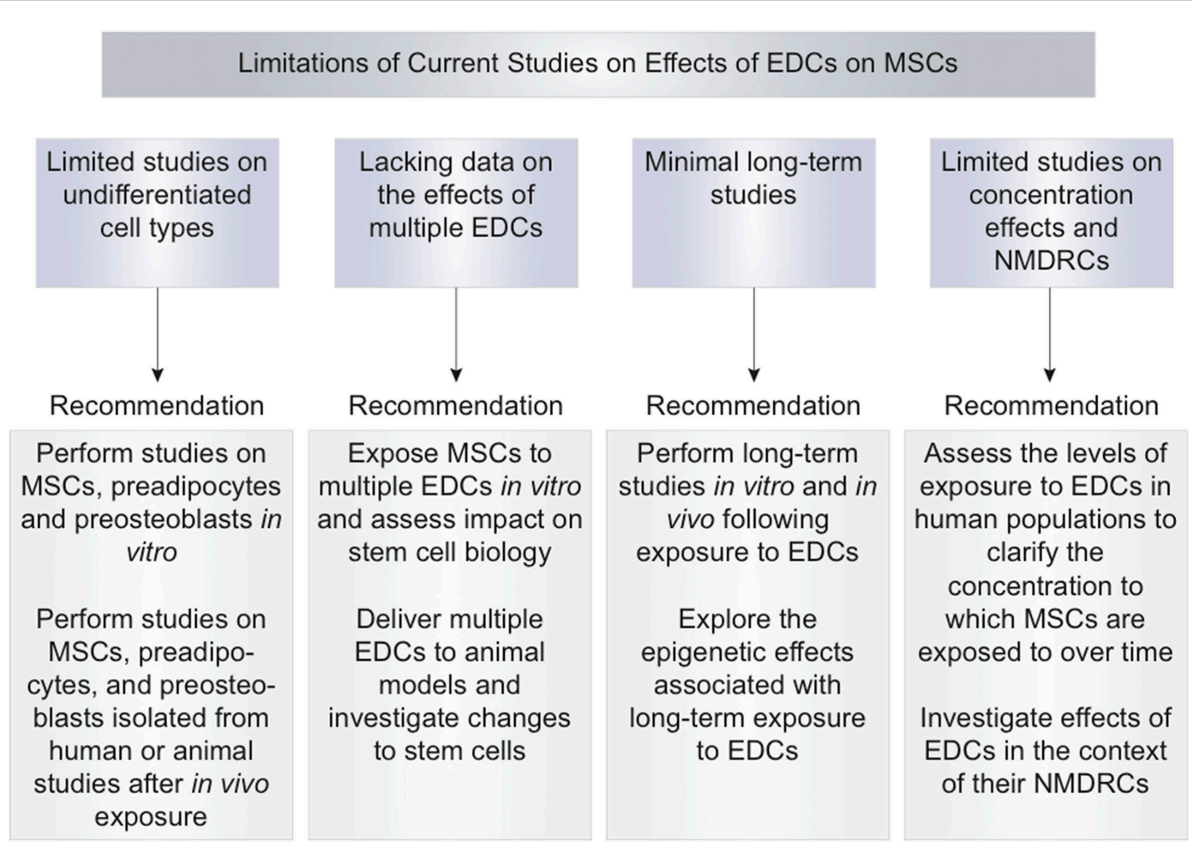

FIGURE 3 | Limitations of current studies of endocrine-disrupting chemical effects on mesenchymal stem cells and recommendations. 
$\operatorname{PPAR} \gamma, \mathrm{C} / \mathrm{EBP} \alpha$, and $\mathrm{C} / \mathrm{EBP} \beta$ expression has been shown to at least partially occur through a non-classical ER pathway (72). Interestingly, 4-NP exposure in mice has seemingly the opposite effects with the deletion and downregulation of ER $\alpha$ in adipose tissue, as increased adiposity due to fat cell differentiation was observed in mice (83).

Endocrine-disrupting chemicals can also increase adipogenesis in a paracrine manner by affecting soluble cues in the preadipocyte or MSC environment. Leptin, an anti-obesity hormone, has been shown to promote the use of metabolic fuels such as fatty acids rather than storage of fatty acids to form triglycerides. PCB-101, PCB-153, and PCB-180 at $1 \mu \mathrm{M}$ concentrations have been shown to increase lipid accumulation and indirectly induce adipogenesis by inhibiting leptin (74).

Together, these results suggest that EDCs have the capacity to induce adipogenesis of MSCs and preadipocytes through increases in PPAR $\gamma$ signaling and alterations in the molecular environment. Increased adipogenic differentiation may lead to a reduced number of MSCs committing to the osteoblastic lineage and may reduce the ability of MSCs to undergo osteogenic differentiation (Figure 1). More studies should be performed with concentrations of EDCs in the picomolar to nanomolar range as EDCs may exert additional effects at these concentrations (21-23). Further limitations of the current studies in this field are the limited number of studies performed on undifferentiated, stem cells and the lack of data on the effects of exposure to multiple EDCs (Figure 3). Areas for improvement include implementation of more studies involving MSC exposure to EDCs and multiple EDCs simultaneously (Figure 3).

\section{OSTEOGENESIS}

Osteogenesis is the differentiation of MSCs into osteoblasts. Osteogenic differentiation is driven by Runx2, a transcription factor that regulates the expression levels of osteogenic genes. These genes include alkaline phosphatase (94), osteopontin, type I collagen, osteocalcin, and osterix $(6,94)$. There are several other signaling pathways involved in osteogenic differentiation, including bone morphogenetic protein (BMP), transforming growth factor beta (TGF- $\beta$ ), and Wnt/ $\beta$-catenin signaling. Similar to adipogenesis, osteogenic differentiation relies on a mechanical stimulus with the appropriate growth surface stiffness, topography, tension, cytoskeletal organization, and soluble medium factors (95-99). A general principle is that stimulation of adipogenesis results in suppression of osteogenesis and viceversa $(76,100-102)$. Thus, given the induction of adipogenesis by many EDCs, it is logical that EDCs have been shown to reduce the expression of genes and activity of transcription factors involved in MSCs undergoing osteogenic differentiation.

Several EDCs have been shown to reduce expression of Runx2 and other key osteogenic genes at varying stages of bone differentiation. Chlorpyrifos has been shown to inhibit osteogenesis in MSCs through inhibition of acetylcholinesterase, leading to an increase in acetylcholine (103). Increased acetylcholine has been shown to reduce ALP activity by nicotinic acetylcholine receptors and muscarinic acetylcholine receptors in preosteoblasts and osteoblasts, reducing osteogenic differentiation (104). MEHP has been shown to significantly suppress ALP activity, Runx2 expression, and osterix expression in MSCs (76). DEHP results in reduction of ALP expression, Runx2 protein levels, and mineralization in osteoblasts (105). The mechanisms by which $10 \mu \mathrm{M}$ of MEHP and DEHP and $20 \mu \mathrm{M}$ of MEHP inhibited osteogenesis were not determined in these studies, although Watt and Schlezinger and Bhat et al. demonstrated that the reduction in osteogenesis was not a result of decreased cell viability.

One proven mechanism of reduction of MSC osteogenesis by EDCs is their induction of apoptosis of osteoblast lineage cells. A total of $2.5 \mu \mathrm{M}$ of $\mathrm{p}-\mathrm{NP}$ has been shown to reduce osteogenesis of MSCs and to reduce cell viability (106). Aroclor 1254 and BPA have been reported to reduce osteogenesis of preosteoblasts and to reduce cell viability at concentrations ranging from 1 to $10 \mu \mathrm{M}$ for Aroclor 1254 and from 2.5 to $12.5 \mu \mathrm{M}$ for $\mathrm{BPA}(107,108)$. A total of $1-10 \mu \mathrm{M}$ concentrations of $4-\mathrm{NP}, \mathrm{BBP}$, and DBP have also been shown to decrease viability of osteoblasts and preosteoblasts through promotion of apoptotic pathways (109, 110). Notably, the EDC effects in these studies occurred in a dose-dependent manner with higher doses of EDCs being more likely to result in reduced cell viability and decreased osteogenic differentiation. EDCs exert their effects over long-term environmental exposures.

One additional potential mechanism for the reduction in MSC osteogenic differentiation is the alteration of the cellular microenvironment through EDC reduction of serum estradiol levels. Estradiol has been shown to induce MSC differentiation toward an osteogenic lineage and to increase MSC expression of osteogenic genes including Runx2, ALP, collagen I, TGF- $\beta 1$, and BMP2 (91, 111-114). EDCs including chlorpyrifos, OP, BPA, DEHP, MEHP, DBP, and mono-butyl phthalate (MBP) have been shown to reduce serum estradiol and testosterone levels (115-122). EDC reduction in the level of estradiol in the MSC microenvironment may cause MSCs to shift away from an osteogenic lineage and toward an adipogenic lineage. The reduction in serum estradiol and the mechanisms by which it may affect MSCs must be further investigated in future studies.

These studies suggest that EDCs may alter the capacity of MSCs to undergo osteogenic differentiation by reducing cell viability and altering cell microenvironment (Figure 1). A strength of the studies on the osteogenic effects of EDCs was the use of a treatment period that is classified as "long-term" or greater than or equal to 7 days. Long-term treatment periods more accurately mimic the effects of chronic environmental exposure to EDCs. Limitations of current studies of EDC inhibition of osteogenesis include lack of studies testing EDC concentrations in the picomolar to nanomolar range, lack of studies in MSCs and preosteoblasts, and lack of assessment of exposure to multiple EDCs simultaneously (Figure 3). Areas for improvement include implementation of more studies using low concentrations of EDCs, in vitro studies testing various EDCs in MSCs and preosteoblasts, in vivo studies of MSCs isolated from EDC-exposed animal subjects, and studies of exposure to multiple EDCs simultaneously (Figure 3).

\section{OXIDATIVE STRESS}

Oxidative stress is an imbalance in the production of free radicals and detoxification by antioxidants. Oxidative stress can be 
measured by alterations in the levels and activity of antioxidant enzymes, such as superoxide dismutase, catalase, glutathione (GSH) peroxidase levels, the GSH/glutathione disulfide ratio, and malondialdehyde levels. These enzymes detoxify reactive oxygen species (ROS) by reducing them to water and other unharmful forms, preventing cellular damage and aging. Alterations in the levels of these enzymes can prevent the cell and organism from being adequately protected against ROS. Cellular aging is the decreased efficiency of function that occurs from damage from processes such as oxidative stress over time (123).

Oxidative stress has been associated with reduced self-renewal and early senescence of stem cells. While EDCs have been shown to induce ROS in a variety of cell types, studies have not been performed directly on MSCs. DEHP has been shown to promote oxidative stress and increase ROS in adipocytes (124). BPA has been shown to increase structural chromosome aberrations in bone marrow cells likely secondary to oxidative stress (125). ROS alter MSC biology by inhibiting osteogenesis, and increased ROS levels are associated with MSCs undergoing adipogenic differentiation (126). Additionally, MSCs exposed to ROS during expansion and MSCs from older subjects have reduced T cell suppression capacity due to alterations in MSC immunophenotype (126-128). Oxidative stress also affects the ability to expand MSCs in culture due to replicative senescence and reduced proliferation $(126,129)$. Therefore, it is essential to determine whether EDCs induce ROS in MSCs because ROS may induce changes in MSCs that may affect the ability to expand cells for use in therapy, alter differentiation ability, and reduce immunomodulatory capacity.

The effects of EDCs on ROS generation have not been well described. Limitations of current studies include lack of studies performed directly on MSCs, lack of studies testing various EDCs, lack of testing exposure to multiple EDCs simultaneously, and lack of long-term studies to assess the effects of chronic exposure to ROS. These limitations and areas of improvement to address in future studies are outlined in Figure 3.

\section{PRO-INFLAMMATORY STATE}

Inflammation is a localized response to tissue injury. EDCs including diazinon, parathion, malathion, BPA, PCB-77, PCB153 , and PCB-180 increase the levels of pro-inflammatory cytokines, such as TNF- $\alpha$ and interleukin 6 in adipose tissue $(34,37,48,71,74,81,84,88,130-134)$. Together, these EDC effects induce a pro-inflammatory phenotype in adipose tissue. Animal studies have also demonstrated an increase in pro-inflammatory cytokines in adipose tissue following exposure to parathion and PCB-77 (48, 130).

The pro-inflammatory state induced by EDCs may fundamentally alter MSC biology. In general, MSCs suppress inflammation, and pro-inflammatory cytokines increase the immunomodulatory capacity of MSCs (135-137). While MSCs have immunosuppressive effects in the context of vigorous inflammation, recent studies have demonstrated that low-level inflammation or inhibited expression of immunosuppressive factors such as NOS can result in MSC induction of immune response $(18,138)$. The chronic, subacute exposure to EDCs, such as diazinon, parathion, malathion, BPA, PCB-77, PCB-153, and PCB-180, may induce low-level inflammation, leading to increased pro-inflammatory cytokines secreted by MSCs and induction of the immune response (18).

Pro-inflammatory effects of EDCs may also have an effect on MSC differentiation. Interestingly, pro-inflammatory conditions may increase expression of osteogenic genes such as ALP and result in increased mineralization $(139,140)$. Li et al. further demonstrated that conditioned medium from TNF- $\alpha$-activated MSCs can enhance osteogenesis through paracrine mechanisms (139). However, Sidney and colleagues demonstrated decreases in cell viability and reduction in formation of bone nodules by primary osteoblasts in response to cytokine stimulation (141). These two opposing studies may be explained by differences in long-term and short-term exposures to pro-inflammatory conditions. In a study of long-term exposure to pro-inflammatory cytokines (TNF- $\alpha$ and interleukin 1 beta), stem cells from the apical papilla demonstrated inhibition of osteogenesis while in short-term culture, cytokines induced mineralization (142). A similar study in bone marrow MSCs demonstrated promotion of osteogenesis with short-term TNF- $\alpha$ exposure and inhibition of osteogenesis with long-term exposure (143). In these two studies, inhibition of osteogenesis occurred at greater than or equal to 7 days while promotion of osteogenesis occurred at time points less than 7 days. This is the reasoning behind our definitions of short-term and long-term exposure to inflammation throughout this review. The model of EDC effects is more likely to represent a long-term exposure and thus to decrease osteogenesis.

In summary, these studies indicate that long-term exposure to EDCs may result in MSC induction of a pro-inflammatory state that can inhibit osteogenesis. The primary strength of these studies stressed the long-term effects of EDCs and the differential effects of short and long-term exposure to EDCs. Limitations include lack of studies demonstrating induction of inflammatory state directly in MSCs and lack of studies on effects of exposure to multiple EDCs simultaneously. Future studies should investigate the pro-inflammatory state of MSCs after in vitro and in vivo EDC exposures (Figure 3). Additionally, the effects of multiple endocrine disruptors should be tested simultaneously in MSCs to improve understanding of environmental exposures of humans to multiple EDCs (Figure 3).

\section{DEVELOPMENT OF EPIGENETIC CHANGES}

Epigenetic changes are alterations in gene activity that do not alter DNA sequence. EDCs can induce epigenetic changes in the undifferentiated cells of the fetus or in undifferentiated adult stem cells by oxidative stress or changes in ligand signaling. Epigenetic changes following EDC exposure include alterations in DNA methylation, histone acetylation, and microRNA (miRNA) expression. Several of the epigenetic changes induced by EDCs may explain their propensity to induce adipogenesis and inhibit osteogenesis. These epigenetic changes can also be passed to subsequent generations of stem cells and if present in the germline, can persist in subsequent generations of offspring $(21,23,29,31$, 40, 42, 144). 
Epigenetic effects of EDCs may be key in the induction of adipogenesis and the inhibition of osteogenesis in MSCs. The non-canonical Wnt/ $\beta$-catenin pathway, which has been associated with osteogenic differentiation, has been shown to inhibit PPAR $\gamma$ transactivation by $\mathrm{H} 3 \mathrm{~K} 9$ methylation of its target genes (145). Inhibition of PPAR $\gamma$ results in a shift toward osteogenic differentiation while decreased methylation would activate PPAR $\gamma$ and shift toward adipogenic differentiation. BBP has been directly shown to cause histone modifications that induce MSCs to undergo adipogenic differentiation such as the enhancement of $\mathrm{H} 3 \mathrm{~K} 9$ acetylation, the increase of histone acetyltransferases such as p300 expression and GCN5 expression, the reduction of histone deacetylase expression, and the decreased dimethylation of H3K9 (75). Notably, these effects were seen at $100 \mathrm{nM}$ to $50 \mu \mathrm{M}$ concentrations of BBP with the decreased dimethylation effect occurring in the concentration range of $100 \mathrm{nM}$ to $10 \mu \mathrm{M}$. Decreased trimethylation of histone H3K9(me3) and increased expression of miR-146a have also been shown in multiple cell types following exposure to BPA but have not yet been directly shown in MSCs $(123,146,147)$.

Data regarding the epigenetic effects induced by EDCs are preliminary. In vitro studies on the epigenetic effects should specifically be performed in MSCs isolated from various tissues. Once in vitro EDC epigenetic effects in MSCs are clarified, MSCs should be isolated from human subjects of various ages and tested for EDC-specific epigenetic changes. These subjects should also have serum levels of EDCs tested at multiple time points to identify the concentration of EDCs to which human subjects and their stem cells are exposed over time. Studying the EDC-induced epigenetic changes in MSCs in humans exposed to EDCs present in the environment would provide information about cumulative, lifetime EDC exposures in potential MSC donors (Figure 3).

\section{POTENTIAL IMPLICATIONS OF EDC EXPOSURE ON THERAPEUTIC POTENTIAL OF MSCs}

\section{Effect on Tissue Engineering}

The observed adipogenic effects and potential ROS-inducing effects of EDCs, such as DDT, BPA, alkylphenols, PCBs, and phthalates, on MSCs have important implications with regard to tissue engineering. The therapeutic efficacy of MSCs with regard to the repair of defects and fractures is twofold. MSCs must be able to differentiate into appropriate lineages, and they must be able to secrete appropriate paracrine factors that recruit other host cells and stimulate regeneration of the damaged tissue (4, 7-9).

One well-described effect of EDCs in the literature is the induction of adipogenesis and inhibition of osteogenesis in MSCs. In the context of tissue engineering for critical-sized defects and fractures, tissue scaffolds may be seeded with MSCs that have been exposed to EDCs, and the EDC exposure may impair the capacity of the MSCs for osteogenic differentiation. This leads to decreased bone formation, representing the impaired ability of MSCs to heal critical-sized defects and fractures. EDC-exposed MSCs may undergo adipogenesis, further reducing the ability of MSCs to directly regenerate damaged tissues and to promote wound healing. An additional point of consideration is that MSCs may be exposed to EDCs in the MSC donor or through high serum concentrations of EDCs in the MSC recipient. Thus, exposure of the MSC donor or the MSC recipient to EDCs may reduce the ability of the MSCs to promote wound healing by driving MSCs toward adipogenic differentiation.

In addition to induction of adipogenesis, EDC promotion of ROS production may reduce the capacity of MSCs to self-renew and differentiate, resulting in cellular senescence and aging. Studies of aged MSCs have demonstrated a reduced capacity for activation, migration, and differentiation $(128,148)$. Donors with greater lifetime exposure may have more aged MSCs, and seeding tissue scaffolds with these aged MSCs may result in a reduced capacity to regenerate damaged tissues and to recruit other cells to the site of injury. When determining an appropriate MSC donor source for promotion of wound healing, the lifetime exposure of the donor to EDCs should be carefully considered. A potential method for considering lifetime exposure is outlined in the Section "Development of Epigenetic Changes."

Therefore, EDCs may reduce the therapeutic efficacy of MSCs in wound healing by inducing adipogenic differentiation and promoting ROS production. These EDC effects impair differentiation of MSCs into appropriate lineages for wound healing, MSC recruitment of other host cells, and stimulation of damaged tissue regeneration by MSCs. Future in vivo studies of tissue engineering should test the capacity of MSCs to regenerate damaged tissues and heal critical-sized defects in the context of EDC exposure. It is particularly essential to collect these data as animal subjects in tissue engineering studies may have natural levels of exposure to EDCs that do not accurately reflect the exposure of human subjects to EDCs.

\section{Effect on Immunomodulatory Capacity}

The immunomodulatory capacity of MSCs is likely altered by exposures to EDCs, such as organophosphates, DDT, BPA, alkylphenols, PCBs, and phthalates. The ability to use MSCs to increase survival of allografts, reduce graft-versus-host disease, accelerate wound healing, and improve outcomes in demyelinating diseases is also twofold. MSCs suppress pro-inflammatory conditions and have various effects on the immune system $(8,9$, 14-18). The therapeutic efficacy of MSCs is also contingent upon the lack of immunogenicity of the MSCs themselves to prevent pro-inflammatory reaction upon treatment.

The effects of EDCs in altering immunomodulatory capacity of MSCs include the promotion of oxidative stress and induction of adipogenesis. MSCs exposed to oxidative stress and MSCs which have undergone cellular senescence have shown reduced ability to suppress inflammation (148). Therefore, donor MSCs that have been aged by exposure to EDCs may have less therapeutic effect in conditions such as multiple sclerosis. Additionally, EDC-induced ROS production may upregulate adipogenic differentiation in MSCs. MSCs undergoing adipogenesis have been demonstrated to have a slightly different immunophenotype and secretome from MSCs not committed to a lineage, which could result in increased immunogenicity upon treatment $(149,150)$. 
The chronic, subacute inflammatory state induced by EDCs has further been shown to increase secretion of pro-inflammatory cytokines by MSCs $(8,18,151,152)$. This could lead to impaired wound healing, acute graft loss, worsening of graft-versus-host disease, and worsened outcomes in demyelinating diseases. However, MSCs have also been shown to have stronger immunosuppressive effects in the context of higher levels of inflammation, levels which may be present in autoimmune diseases. It is possible that upon inoculation, donor MSCs may be exposed to a sufficient level of inflammation to induce their immunosuppressive properties.

Therefore, EDCs impair the capacity of MSCs to immunomodulate pro-inflammatory conditions by inducing adipogenesis, promoting oxidative stress, and causing a chronic, subacute pro-inflammatory state. These changes may result in reduced immunosuppression and increased immunogenicity of MSCs. Further studies are needed in vivo that examine the immunomodulatory capacity of MSCs following EDC exposure. It is possible that animals are not exposed to the same levels of EDCs and thus are not accounting for potentially reduced capacity of MSCs to improve outcomes in pro-inflammatory conditions following the exposure to EDCs.

\section{CONCLUSION}

Endocrine-disrupting chemicals may alter the therapeutic potential of MSCs by effects on MSC differentiation capacity

\section{REFERENCES}

1. Dominici M, Le Blanc K, Mueller I, Slaper-Cortenbach I, Marini F, Krause D, et al. Minimal criteria for defining multipotent mesenchymal stromal cells. The International Society for Cellular Therapy position statement. Cytotherapy (2006) 8(4):315-7. doi:10.1080/14653240600855905

2. Bruder SP, Jaiswal N, Haynesworth SE. Growth kinetics, self-renewal, and the osteogenic potential of purified human mesenchymal stem cells during extensive subcultivation and following cryopreservation. J Cell Biochem (1997) 64(2):278-94.

3. Ksiazek K. A comprehensive review on mesenchymal stem cell growth and senescence. Rejuvenation Res (2009) 12(2):105-16. doi:10.1089/rej. 2009.0830

4. Augello A, Kurth TB, De Bari C. Mesenchymal stem cells: a perspective from in vitro cultures to in vivo migration and niches. Eur Cell Mater (2010) 20:121-33. doi:10.22203/eCM.v020a11

5. Mosna F, Sensebe L, Krampera M. Human bone marrow and adipose tissue mesenchymal stem cells: a user's guide. Stem Cells Dev (2010) 19(10):1449-70. doi: $10.1089 /$ scd. 2010.0140

6. Hayrapetyan A, Jansen JA, van den Beucken JJ. Signaling pathways involved in osteogenesis and their application for bone regenerative medicine. Tissue Eng Part B Rev (2015) 21(1):75-87. doi:10.1089/ten.TEB. 2014.0119

7. Schipani E, Kronenberg HM. Adult Mesenchymal Stem Cells StemBook. Cambridge, MA: The Harvard Stem Cell Institute (2008).

8. Maxson S, Lopez EA, Yoo D, Danilkovitch-Miagkova A, Leroux MA. Concise review: role of mesenchymal stem cells in wound repair. Stem Cells Transl Med (2012) 1(2):142-9. doi:10.5966/sctm.2011-0018

9. Prockop DJ. "Stemness" does not explain the repair of many tissues by mesenchymal stem/multipotent stromal cells (MSCs). Clin Pharmacol Ther (2007) 82(3):241-3. doi:10.1038/sj.clpt.6100313

10. Barrilleaux B, Phinney DG, Prockop DJ, O'Connor KC. Review: ex vivo engineering of living tissues with adult stem cells. Tissue Eng (2006) 12(11):3007-19. doi:10.1089/ten.2006.12.3007 and biologic properties, including induction of adipogenesis, inhibition of osteogenesis, increase in oxidative stress, and promotion of a pro-inflammatory state. These effects may lead to reduced capacity of MSCs to differentiate into appropriate lineages and to induce paracrine signaling in wound healing. Additionally, they may decrease immunomodulatory effects by MSCs. The implications for tissue engineering and treatment of pro-inflammatory conditions are concerning and should be further explored with in vivo exposures to EDCs in animal subjects and studies of these potential effects on therapeutic efficacy. All of the alterations in MSC biology that result in changed therapeutic potential may ultimately be rooted in epigenetic alterations induced by EDCs that remain to be clarified, so future in vitro and in vivo studies should also explore epigenetic effects of EDCs on MSCs isolated from various tissues in the body. EDC-induced effects on MSCs should be considered when analyzing results of previous studies and should be further explored in future studies to more fully understand the implications for MSC therapies.

\section{AUTHOR CONTRIBUTIONS}

ME Bateman participated in the literature searches, design, writing, and editing of this review. AS participated in design, writing, and editing of the review. JM and ME Burow participated in the design and editing of this review. BB participated in the design, writing, and editing of this review.

11. Black CR, Goriainov V, Gibbs D, Kanczler J, Tare RS, Oreffo RO. Bone tissue engineering. Curr Mol Biol Rep (2015) 1(3):132-40. doi:10.1007/ s40610-015-0022-2

12. Levi B, James AW, Nelson ER, Vistnes D, Wu B, Lee M, et al. Human adipose derived stromal cells heal critical size mouse calvarial defects. PLoS One (2010) 5(6):e11177. doi:10.1371/journal.pone.0011177

13. Verrier S, Alini M, Alsberg E, Buchman SR, Kelly D, Laschke MW, et al. Tissue engineering and regenerative approaches to improving the healing of large bone defects. Eur Cell Mater (2016) 32:87-110. doi:10.22203/eCM. v032a06

14. Rahimzadeh A, Tabatabaei Mirakabad FS, Movassaghpour A, Shamsasenjan K, Kariminekoo S, Talebi M, et al. Biotechnological and biomedical applications of mesenchymal stem cells as a therapeutic system. ArtifCells Nanomed Biotechnol (2016) 44(2):559-70. doi:10.3109/21691401.2014.968823

15. Marti LC, Ribeiro AA, Hamerschlak N. Immunomodulatory effect of mesenchymal stem cells. Einstein (Sao Paulo) (2011) 9(2):224-8. doi:10.1590/ S1679-45082011RW1843

16. Zhao S, Wehner R, Bornhauser M, Wassmuth R, Bachmann M, Schmitz M. Immunomodulatory properties of mesenchymal stromal cells and their therapeutic consequences for immune-mediated disorders. Stem Cells Dev (2010) 19(5):607-14. doi:10.1089/scd.2009.0345

17. Ghannam S, Bouffi C, Djouad F, Jorgensen C, Noel D. Immunosuppression by mesenchymal stem cells: mechanisms and clinical applications. Stem Cell Res Ther (2010) 1(1):2. doi:10.1186/scrt2

18. Ma S, Xie N, Li W, Yuan B, Shi Y, Wang Y. Immunobiology of mesenchymal stem cells. Cell Death Differ (2014) 21(2):216-25. doi:10.1038/cdd. 2013.158

19. Ren G, Chen X, Dong F, Li W, Ren X, Zhang Y, et al. Concise review: mesenchymal stem cells and translational medicine: emerging issues. Stem Cells Transl Med (2012) 1(1):51-8. doi:10.5966/sctm.2011-0019

20. Yoon K, Kwack SJ, Kim HS, Lee BM. Estrogenic endocrine-disrupting chemicals: molecular mechanisms of actions on putative human diseases. J Toxicol Environ Health B Crit Rev (2014) 17(3):127-74. doi:10.1080/ 10937404.2014.882194 
21. Schug TT, Janesick A, Blumberg B, Heindel JJ. Endocrine disrupting chemicals and disease susceptibility. J Steroid Biochem Mol Biol (2011) 127(3-5):204-15. doi:10.1016/j.jsbmb.2011.08.007

22. Vandenberg LN, Colborn T, Hayes TB, Heindel JJ, Jacobs DR Jr, Lee DH, et al. Hormones and endocrine-disrupting chemicals: low-dose effects and nonmonotonic dose responses. Endocr Rev (2012) 33(3):378-455. doi:10.1210/ er.2011-1050

23. Schug TT, Johnson AF, Birnbaum LS, Colborn T, Guillette LJ Jr, Crews DP, et al. Minireview: endocrine disruptors: past lessons and future directions. Mol Endocrinol (2016) 30(8):833-47. doi:10.1210/me.2016-1096

24. McLachlan JA. Environmental signaling: what embryos and evolution teach us about endocrine disrupting chemicals. Endocr Rev (2001) 22(3):319-41. doi:10.1210/edrv.22.3.0432

25. Janesick A, Blumberg B. Endocrine disrupting chemicals and the developmental programming of adipogenesis and obesity. Birth Defects Res C Embryo Today (2011) 93(1):34-50. doi:10.1002/bdrc.20197

26. Rosen ED, Hsu CH, Wang X, Sakai S, Freeman MW, Gonzalez FJ, et al. C/EBPalpha induces adipogenesis through PPARgamma: a unified pathway. Genes Dev (2002) 16(1):22-6. doi:10.1101/gad.948702

27. Zhang DY, Pan Y, Zhang C, Yan BX, Yu SS, Wu DL, et al. Wnt/beta-catenin signaling induces the aging of mesenchymal stem cells through promoting the ROS production. Mol Cell Biochem (2013) 374(1-2):13-20. doi:10.1007/ s11010-012-1498-1

28. Lee DH, Porta M, Jacobs DR Jr, Vandenberg LN. Chlorinated persistent organic pollutants, obesity, and type 2 diabetes. Endocr Rev (2014) 35(4):557-601. doi:10.1210/er.2013-1084

29. Crews D, McLachlan JA. Epigenetics, evolution, endocrine disruption, health, and disease. Endocrinology (2006) 147(6 Suppl):S4-10. doi:10.1210/ en.2005-1122

30. de Cock M, van de Bor M. Obesogenic effects of endocrine disruptors, what do we know from animal and human studies? Environ Int (2014) 70:15-24. doi:10.1016/j.envint.2014.04.022

31. Vom Saal FS, Nagel SC, Coe BL, Angle BM, Taylor JA. The estrogenic endocrine disrupting chemical bisphenol A (BPA) and obesity. Mol Cell Endocrinol (2012) 354(1-2):74-84. doi:10.1016/j.mce.2012.01.001

32. Heindel JJ, Newbold R, Schug TT. Endocrine disruptors and obesity. Nat Rev Endocrinol (2015) 11(11):653-61. doi:10.1038/nrendo.2015.163

33. Meggs WJ, Brewer KL. Weight gain associated with chronic exposure to chlorpyrifos in rats. J Med Toxicol (2007) 3(3):89-93. doi:10.1007/ BF03160916

34. Yang $M$, Chen M, Wang J, Xu M, Sun J, Ding L, et al. Bisphenol A promotes adiposity and inflammation in a nonmonotonic dose-response way in 5-week-old male and female C57BL/6J mice fed a low-calorie diet. Endocrinology (2016) 157(6):2333-45. doi:10.1210/en.2015-1926

35. Biasiotto G, Zanella I, Masserdotti A, Pedrazzani R, Papa M, Caimi L, et al. Municipal wastewater affects adipose deposition in male mice and increases 3T3-L1 cell differentiation. Toxicol Appl Pharmacol (2016) 297:32-40. doi:10.1016/j.taap.2016.02.023

36. Wahlang B, Falkner KC, Gregory B, Ansert D, Young D, Conklin DJ, et al. Polychlorinated biphenyl 153 is a diet-dependent obesogen that worsens nonalcoholic fatty liver disease in male C57BL6/J mice. J Nutr Biochem (2013) 24(9):1587-95. doi:10.1016/j.jnutbio.2013.01.009

37. Arsenescu V, Arsenescu RI, King V, Swanson H, Cassis LA. Polychlorinated biphenyl-77 induces adipocyte differentiation and proinflammatory adipokines and promotes obesity and atherosclerosis. Environ Health Perspect (2008) 116(6):761-8. doi:10.1289/ehp.10554

38. Lassiter TL, Brimijoin S. Rats gain excess weight after developmental exposure to the organophosphorothionate pesticide, chlorpyrifos. Neurotoxicol Teratol (2008) 30(2):125-30. doi:10.1016/j.ntt.2007.10.004

39. Hao CJ, Cheng XJ, Xia HF, Ma X. The endocrine disruptor 4-nonylphenol promotes adipocyte differentiation and induces obesity in mice. Cell Physiol Biochem (2012) 30(2):382-94. doi:10.1159/000339032

40. Newbold RR. Impact of environmental endocrine disrupting chemicals on the development of obesity. Hormones (Athens) (2010) 9(3):206-17. doi:10.14310/horm.2002.1271

41. Ross MG, Desai M. Developmental programming of offspring obesity, adipogenesis, and appetite. Clin Obstet Gynecol (2013) 56(3):529-36. doi:10.1097/GRF.0b013e318299c39d
42. Fudvoye J, Bourguignon JP, Parent AS. Endocrine-disrupting chemicals and human growth and maturation: a focus on early critical windows of exposure. Vitam Horm (2014) 94:1-25. doi:10.1016/B978-0-12-8000953.00001-8

43. Pereira-Fernandes A, Demaegdt H, Vandermeiren K, Hectors TL, Jorens PG, Blust R, et al. Evaluation of a screening system for obesogenic compounds: screening of endocrine disrupting compounds and evaluation of the PPAR dependency of the effect. PLoS One (2013) 8(10):e77481. doi:10.1371/ journal.pone.0077481

44. Miyawaki J, Sakayama K, Kato H, Yamamoto H, Masuno H. Perinatal and postnatal exposure to bisphenol a increases adipose tissue mass and serum cholesterol level in mice. J Atheroscler Thromb (2007) 14(5):245-52. doi:10.5551/jat.E486

45. Somm E, Schwitzgebel VM, Toulotte A, Cederroth CR, Combescure C, Nef S, et al. Perinatal exposure to bisphenol a alters early adipogenesis in the rat. Environ Health Perspect (2009) 117(10):1549-55. doi:10.1289/ ehp. 11342

46. Wang J, Sun B, Hou M, Pan X, Li X. The environmental obesogen bisphenol A promotes adipogenesis by increasing the amount of 11 betahydroxysteroid dehydrogenase type 1 in the adipose tissue of children. Int J Obes (Lond) (2013) 37(7):999-1005. doi:10.1038/ijo.2012.173

47. Schmidt JS, Schaedlich K, Fiandanese N, Pocar P, Fischer B. Effects of di(2-ethylhexyl)phthalate (DEHP) on female fertility and adipogenesis in C3H/N mice. Environ Health Perspect (2012) 120(8):1123-9. doi:10.1289/ ehp. 1104016

48. Lassiter TL, Ryde IT, Levin ED, Seidler FJ, Slotkin TA. Neonatal exposure to parathion alters lipid metabolism in adulthood: interactions with dietary fat intake and implications for neurodevelopmental deficits. Brain Res Bull (2010) 81(1):85-91. doi:10.1016/j.brainresbull.2009.07.002

49. Rochester JR. Bisphenol A and human health: a review of the literature. Reprod Toxicol (2013) 42:132-55. doi:10.1016/j.reprotox.2013.08.008

50. Talsness CE, Andrade AJ, Kuriyama SN, Taylor JA, vom Saal FS. Components of plastic: experimental studies in animals and relevance for human health. Philos Trans R Soc Lond B Biol Sci (2009) 364(1526):2079-96. doi:10.1098/ rstb.2008.0281

51. Oppeneer SJ, Robien K. Bisphenol A exposure and associations with obesity among adults: a critical review. Public Health Nutr (2015) 18(10):1847-63. doi:10.1017/S1368980014002213

52. Rezg R, El-Fazaa S, Gharbi N, Mornagui B. Bisphenol A and human chronic diseases: current evidences, possible mechanisms, and future perspectives. Environ Int (2014) 64:83-90. doi:10.1016/j.envint.2013.12.007

53. Thayer KA, Heindel JJ, Bucher JR, Gallo MA. Role of environmental chemicals in diabetes and obesity: a National Toxicology Program workshop review. Environ Health Perspect (2012) 120(6):779-89. doi:10.1289/ ehp. 1104597

54. Taylor KW, Novak RF, Anderson HA, Birnbaum LS, Blystone C, Devito M, et al. Evaluation of the association between persistent organic pollutants (POPs) and diabetes in epidemiological studies: a national toxicology program workshop review. Environ Health Perspect (2013) 121(7):774-83. doi:10.1289/ehp.1205502

55. Tang-Peronard JL, Andersen HR, Jensen TK, Heitmann BL. Endocrinedisrupting chemicals and obesity development in humans: a review. Obes Rev (2011) 12(8):622-36. doi:10.1111/j.1467-789X.2011.00871.x

56. Mullerova D, Kopecky J, Matejkova D, Muller L, Rosmus J, Racek J, et al. Negative association between plasma levels of adiponectin and polychlorinated biphenyl 153 in obese women under non-energy-restrictive regime. Int J Obes (Lond) (2008) 32(12):1875-8. doi:10.1038/ijo. 2008.169

57. Lim JE, Jee SH. Association between serum levels of adiponectin and polychlorinated biphenyls in Korean men and women. Endocrine (2015) 48(1):211-7. doi:10.1007/s12020-014-0231-0

58. De Coster S, van Larebeke N. Endocrine-disrupting chemicals: associated disorders and mechanisms of action. JEnviron Public Health (2012) 2012:713696. doi:10.1155/2012/713696

59. Dirinck EL, Dirtu AC, Govindan M, Covaci A, Van Gaal LF, Jorens PG. Exposure to persistent organic pollutants: relationship with abnormal glucose metabolism and visceral adiposity. Diabetes Care (2014) 37(7):1951-8. doi:10.2337/dc13-2329 
60. Gauthier MS, Rabasa-Lhoret R, Prud'homme D, Karelis AD, Geng D, van Bavel B, et al. The metabolically healthy but obese phenotype is associated with lower plasma levels of persistent organic pollutants as compared to the metabolically abnormal obese phenotype. J Clin Endocrinol Metab (2014) 99(6):E1061-6. doi:10.1210/jc.2013-3935

61. Hatch EE, Nelson JW, Qureshi MM, Weinberg J, Moore LL, Singer M, et al. Association of urinary phthalate metabolite concentrations with body mass index and waist circumference: a cross-sectional study of NHANES data, 1999-2002. Environ Health (2008) 7:27. doi:10.1186/1476-069X-7-27

62. Meeker JD, Sathyanarayana S, Swan SH. Phthalates and other additives in plastics: human exposure and associated health outcomes. Philos Trans R Soc Lond B Biol Sci (2009) 364(1526):2097-113. doi:10.1098/rstb. 2008.0268

63. Kim SH, Park MJ. Phthalate exposure and childhood obesity. Ann Pediatr Endocrinol Metab (2014) 19(2):69-75. doi:10.6065/apem.2014.19.2.69

64. Kuo CC, Moon K, Thayer KA, Navas-Acien A. Environmental chemicals and type 2 diabetes: an updated systematic review of the epidemiologic evidence. Curr Diab Rep (2013) 13(6):831-49. doi:10.1007/s11892-0130432-6

65. Hou JW, Lin CL, Tsai YA, Chang CH, Liao KW, Yu CJ, et al. The effects of phthalate and nonylphenol exposure on body size and secondary sexual characteristics during puberty. Int J Hyg Environ Health (2015) 218(7):603-15. doi:10.1016/j.ijheh.2015.06.004

66. Moreno-Aliaga MJ, Matsumura F. Effects of 1,1,1-trichloro-2,2-bis(p-chlorophenyl)-ethane (p,p'-DDT) on 3T3-L1 and 3T3-F442A adipocyte differentiation. Biochem Pharmacol (2002) 63(5):997-1007. doi:10.1016/ S0006-2952(01)00933-9

67. Atlas E, Pope L, Wade MG, Kawata A, Boudreau A, Boucher JG. Bisphenol A increases aP2 expression in 3T3L1 by enhancing the transcriptional activity of nuclear receptors at the promoter. Adipocyte (2014) 3(3):170-9. doi:10.4161/adip.28436

68. Strong AL, Shi Z, Strong MJ, Miller DF, Rusch DB, Buechlein AM, et al. Effects of the endocrine-disrupting chemical DDT on self-renewal and differentiation of human mesenchymal stem cells. Environ Health Perspect (2015) 123(1):42-8. doi:10.1289/ehp.1408188

69. Ohlstein JF, Strong AL, McLachlan JA, Gimble JM, Burow ME, Bunnell BA. Bisphenol A enhances adipogenic differentiation of human adipose stromal/stem cells. J Mol Endocrinol (2014) 53(3):345-53. doi:10.1530/ JME-14-0052

70. Miyawaki J, Kamei S, Sakayama K, Yamamoto H, Masuno H. 4-Tertoctylphenol regulates the differentiation of $\mathrm{C} 3 \mathrm{H} 10 \mathrm{~T} 1 / 2$ cells into osteoblast and adipocyte lineages. Toxicol Sci (2008) 102(1):82-8. doi:10.1093/toxsci/ $\mathrm{kfm} 296$

71. Sargis RM, Johnson DN, Choudhury RA, Brady MJ. Environmental endocrine disruptors promote adipogenesis in the 3T3-L1 cell line through glucocorticoid receptor activation. Obesity (Silver Spring) (2010) 18(7):1283-8. doi:10.1038/oby.2009.419

72. Boucher JG, Boudreau A, Atlas E. Bisphenol A induces differentiation of human preadipocytes in the absence of glucocorticoid and is inhibited by an estrogen-receptor antagonist. Nutr Diabetes (2014) 4:e102. doi:10.1038/ nutd. 2013.43

73. Masuno H, Kidani T, Sekiya K, Sakayama K, Shiosaka T, Yamamoto H, et al. Bisphenol A in combination with insulin can accelerate the conversion of 3T3-L1 fibroblasts to adipocytes. J Lipid Res (2002) 43(5):676-84.

74. Ferrante MC, Amero P, Santoro A, Monnolo A, Simeoli R, Di Guida F, et al. Polychlorinated biphenyls (PCB 101, PCB 153 and PCB 180) alter leptin signaling and lipid metabolism in differentiated 3T3-L1 adipocytes. Toxicol Appl Pharmacol (2014) 279(3):401-8. doi:10.1016/j.taap. 2014.06.016

75. Sonkar R, Powell CA, Choudhury M. Benzyl butyl phthalate induces epigenetic stress to enhance adipogenesis in mesenchymal stem cells. Mol Cell Endocrinol (2016) 431:109-22. doi:10.1016/j.mce.2016.04.025

76. Watt J, Schlezinger JJ. Structurally-diverse, PPARgamma-activating environmental toxicants induce adipogenesis and suppress osteogenesis in bone marrow mesenchymal stromal cells. Toxicology (2015) 331:66-77. doi:10.1016/j.tox.2015.03.006

77. Hurst CH, Waxman DJ. Activation of PPARalpha and PPARgamma by environmental phthalate monoesters. Toxicol Sci (2003) 74(2):297-308. doi:10.1093/toxsci/kfg145
78. Biemann R, Navarrete Santos A, Navarrete Santos A, Riemann D, Knelangen J, Bluher M, et al. Endocrine disrupting chemicals affect the adipogenic differentiation of mesenchymal stem cells in distinct ontogenetic windows. Biochem Biophys Res Commun (2012) 417(2):747-52. doi:10.1016/ j.bbrc.2011.12.028

79. Desvergne B, Feige JN, Casals-Casas C. PPAR-mediated activity of phthalates: a link to the obesity epidemic? Mol Cell Endocrinol (2009) 304(1-2):43-8. doi:10.1016/j.mce.2009.02.017

80. Shipley JM, Waxman DJ. Simultaneous, bidirectional inhibitory crosstalk between PPAR and STAT5b. Toxicol Appl Pharmacol (2004) 199(3):275-84. doi:10.1016/j.taap.2003.12.020

81. Pakzad M, Fouladdel S, Nili-Ahmadabadi A, Pourkhalili N, Baeeri M, Azizi E, et al. Sublethal exposures of diazinon alters glucose homostasis in Wistar rats: biochemical and molecular evidences of oxidative stress in adipose tissues. Pestic Biochem Physiol (2013) 105(1):57-61. doi:10.1016/ j.pestbp.2012.11.008

82. Kim J, Sun Q, Yue Y, Yoon KS, Whang KY, Marshall Clark J, et al. 4,4'-Dichlorodiphenyltrichloroethane (DDT) and 4,4'-dichlorodiphenyldichloroethylene (DDE) promote adipogenesis in 3T3-L1 adipocyte cell culture. Pestic Biochem Physiol (2016) 131:40-5. doi:10.1016/j.pestbp. 2016.01.005

83. Zhang HY, Xue WY, Li YY, Ma Y, Zhu YS, Huo WQ, et al. Perinatal exposure to 4-nonylphenol affects adipogenesis in first and second generation rats offspring. Toxicol Lett (2014) 225(2):325-32. doi:10.1016/j.toxlet. 2013.12.011

84. Ariemma F, D’Esposito V, Liguoro D, Oriente F, Cabaro S, Liotti A, et al. Low-dose bisphenol-A impairs adipogenesis and generates dysfunctional 3T3-L1 adipocytes. PLoS One (2016) 11(3):e0150762. doi:10.1371/journal. pone. 0150762

85. Boucher JG, Husain M, Rowan-Carroll A, Williams A, Yauk CL, Atlas E. Identification of mechanisms of action of bisphenol a-induced human preadipocyte differentiation by transcriptional profiling. Obesity (Silver Spring) (2014) 22(11):2333-43. doi:10.1002/oby.20848

86. Masuno H, Iwanami J, Kidani T, Sakayama K, Honda K. Bisphenol a accelerates terminal differentiation of 3T3-L1 cells into adipocytes through the phosphatidylinositol 3-kinase pathway. Toxicol Sci (2005) 84(2):319-27. doi:10.1093/toxsci/kfi088

87. Chamorro-Garcia R, Kirchner S, Li X, Janesick A, Casey SC, Chow C, et al. Bisphenol A diglycidyl ether induces adipogenic differentiation of multipotent stromal stem cells through a peroxisome proliferator-activated receptor gamma-independent mechanism. Environ Health Perspect (2012) 120(7):984-9. doi:10.1289/ehp.1205063

88. Menale C, Piccolo MT, Cirillo G, Calogero RA, Papparella A, Mita L, et al. Bisphenol A effects on gene expression in adipocytes from children: association with metabolic disorders. J Mol Endocrinol (2015) 54(3):289-303. doi:10.1530/JME-14-0282

89. Chiang HC, Kuo YT, Shen CC, Lin YH, Wang SL, Tsou TC. Mono(2-ethylhexyl)phthalate accumulation disturbs energy metabolism of fat cells. Arch Toxicol (2016) 90(3):589-601. doi:10.1007/s00204-014-1446-9

90. Jeong S, Yoon M. 17 $\beta$-Estradiol inhibition of PPAR $\gamma$-induced adipogenesis and adipocyte-specific gene expression. Acta Pharmacol Sin (2011) 32(2):230-8. doi:10.1038/aps.2010.198

91. Okazaki R, Inoue D, Shibata M, Saika M, Kido S, Ooka H, et al. Estrogen promotes early osteoblast differentiation and inhibits adipocyte differentiation in mouse bone marrow stromal cell lines that express estrogen receptor (ER) $\alpha$ or $\beta$. Endocrinology (2002) 143(6):2349-56. doi:10.1210/ en.143.6.2349

92. Stubbins RE, Holcomb VB, Hong J, Nunez NP. Estrogen modulates abdominal adiposity and protects female mice from obesity and impaired glucose tolerance. Eur J Nutr (2012) 51(7):861-70. doi:10.1007/s00394011-0266-4

93. Weigt C, Hertrampf T, Kluxen FM, Flenker U, Hulsemann F, Fritzemeier KH, et al. Molecular effects of ER alpha- and beta-selective agonists on regulation of energy homeostasis in obese female Wistar rats. Mol Cell Endocrinol (2013) 377(1-2):147-58. doi:10.1016/j.mce.2013.07.007

94. Ricciardi M, Malpeli G, Bifari F, Bassi G, Pacelli L, Nwabo Kamdje AH, et al. Comparison of epithelial differentiation and immune regulatory properties of mesenchymal stromal cells derived from human lung and bone marrow. PLoS One (2012) 7(5):e35639. doi:10.1371/journal.pone.0035639 
95. Huang C, Dai J, Zhang XA. Environmental physical cues determine the lineage specification of mesenchymal stem cells. Biochim Biophys Acta (2015) 1850(6):1261-6. doi:10.1016/j.bbagen.2015.02.011

96. Steward AJ, Kelly DJ. Mechanical regulation of mesenchymal stem cell differentiation. J Anat (2015) 227(6):717-31. doi:10.1111/joa.12243

97. Hao J, Zhang Y, Jing D, Shen Y, Tang G, Huang S, et al. Mechanobiology of mesenchymal stem cells: perspective into mechanical induction of MSC fate. Acta Biomater (2015) 20:1-9. doi:10.1016/j.actbio.2015.04.008

98. Kilian KA, Bugarija B, Lahn BT, Mrksich M. Geometric cues for directing the differentiation of mesenchymal stem cells. Proc Natl Acad Sci U S A (2010) 107(11):4872-7. doi:10.1073/pnas.0903269107

99. Gregory CA, Ylostalo J, Prockop DJ. Adult bone marrow stem/progenitor cells (MSCs) are preconditioned by microenvironmental "niches" in culture: a two-stage hypothesis for regulation of MSC fate. Sci STKE (2005) 2005(294):pe37. doi:10.1126/stke.2942005pe37

100. Atashi F, Modarressi A, Pepper MS. The role of reactive oxygen species in mesenchymal stem cell adipogenic and osteogenic differentiation: a review. Stem Cells Dev (2015) 24(10):1150-63. doi:10.1089/scd.2014.0484

101. Nuttall ME, Gimble JM. Controlling the balance between osteoblastogenesis and adipogenesis and the consequent therapeutic implications. Curr Opin Pharmacol (2004) 4(3):290-4. doi:10.1016/j.coph.2004.03.002

102. James AW. Review of signaling pathways governing MSC osteogenic and adipogenic differentiation. Scientifica (Cairo) (2013) 2013:684736. doi:10.1155/2013/684736

103. Hoogduijn MJ, Rakonczay Z, Genever PG. The effects of anticholinergic insecticides on human mesenchymal stem cells. Toxicol Sci (2006) 94(2): 342-50. doi:10.1093/toxsci/kfl101

104. Sato T, Abe T, Chida D, Nakamoto N, Hori N, Kokabu S, et al. Functional role of acetylcholine and the expression of cholinergic receptors and components in osteoblasts. FEBS Lett (2010) 584(4):817-24. doi:10.1016/ j.febslet.2010.01.001

105. Bhat FA, Ramajayam G, Parameswari S, Vignesh RC, Karthikeyan S, Senthilkumar K, et al. Di 2-ethyl hexyl phthalate affects differentiation and matrix mineralization of rat calvarial osteoblasts - in vitro. Toxicol In Vitro (2013) 27(1):250-6. doi:10.1016/j.tiv.2012.09.003

106. Abnosi MH, Soleimani Mehranjani M, Shariatzadeh MA, Dehdehi L. Para-nonylphenol impairs osteogenic differentiation of rat bone marrow mesenchymal stem cells by influencing the osteoblasts mineralization. Iran J Basic Med Sci (2012) 15(6):1131-9. doi:10.22038/ijbms. 2012.4931

107. Herlin M, Oberg M, Ringblom J, Joseph B, Korkalainen M, Viluksela M, et al. Inhibitory effects on osteoblast differentiation in vitro by the polychlorinated biphenyl mixture Aroclor 1254 are mainly associated with the dioxin-like constituents. Toxicol In Vitro (2015) 29(5):876-83. doi:10.1016/ j.tiv.2015.03.006

108. Hwang JK, Min KH, Choi KH, Hwang YC, Jeong IK, Ahn KJ, et al. Bisphenol A reduces differentiation and stimulates apoptosis of osteoclasts and osteoblasts. Life Sci (2013) 93(9-11):367-72. doi:10.1016/j.lfs.2013.07.020

109. Sabbieti MG, Agas D, Palermo F, Mosconi G, Santoni G, Amantini C, et al. 4-nonylphenol triggers apoptosis and affects 17-beta-estradiol receptors in calvarial osteoblasts. Toxicology (2011) 290(2-3):334-41. doi:10.1016/ j.tox.2011.10.014

110. Sabbieti MG, Agas D, Santoni G, Materazzi S, Menghi G, Marchetti L. Involvement of p53 in phthalate effects on mouse and rat osteoblasts. J Cell Biochem (2009) 107(2):316-27. doi:10.1002/jcb.22127

111. Zhou S, Zilberman Y, Wassermann K, Bain SD, Sadovsky Y, Gazit D. Estrogen modulates estrogen receptor $\alpha$ and $\beta$ expression, osteogenic activity, and apoptosis in mesenchymal stem cells (MSCs) of osteoporotic mice. J Cell Biochem (2001) 81(S36):144-55. doi:10.1002/jcb.1096

112. Hong L, Colpan A, Peptan IA. Modulations of 17-beta estradiol on osteogenic and adipogenic differentiations of human mesenchymal stem cells. Tissue Eng (2006) 12(10):2747-53. doi:10.1089/ten.2006.12.2747

113. Plant A, Samuels A, Perry MJ, Colley S, Gibson R, Tobias JH. Estrogeninduced osteogenesis in mice is associated with the appearance of Cbfa1-expressing bone marrow cells. J Cell Biochem (2002) 84(2):285-94. doi:10.1002/jcb.10021

114. Qu Q, Perälä-Heape M, Kapanen A, Dahllund J, Salo J, Väänänen HK, et al. Estrogen enhances differentiation of osteoblasts in mouse bone marrow culture. Bone (1998) 22(3):201-9. doi:10.1016/S8756-3282(97)00276-7
115. Ventura C, Nieto MR, Bourguignon N, Lux-Lantos V, Rodriguez H, Cao G, et al. Pesticide chlorpyrifos acts as an endocrine disruptor in adult rats causing changes in mammary gland and hormonal balance. J Steroid Biochem Mol Biol (2016) 156:1-9. doi:10.1016/j.jsbmb. 2015.10.010

116. Herath CB, Jin W, Watanabe G, Arai K, Suzuki AK, Taya K. Adverse effects of environmental toxicants, octylphenol and bisphenol A, on male reproductive functions in pubertal rats. Endocrine (2004) 25(2):163-72. doi:10.1385/ ENDO:25:2:163

117. Chen X, Zhou QH, Leng L, Chen X, Sun ZR, Tang NJ. Effects of di(n-butyl) and monobutyl phthalate on steroidogenesis pathways in the murine Leydig tumor cell line MLTC-1. Environ Toxicol Pharmacol (2013) 36(2):332-8. doi:10.1016/j.etap.2013.04.013

118. Martinez-Arguelles DB, Papadopoulos V. Prenatal phthalate exposure: epigenetic changes leading to lifelong impact on steroid formation. Andrology (2016) 4(4):573-84. doi:10.1111/andr.12175

119. Hannon PR, Brannick KE, Wang W, Gupta RK, Flaws JA. Di(2-ethylhexyl) phthalate inhibits antral follicle growth, induces atresia, and inhibits steroid hormone production in cultured mouse antral follicles. Toxicol Appl Pharmacol (2015) 284(1):42-53. doi:10.1016/j.taap.2015.02.010

120. Lai FN, Liu JC, Li L, Ma JY, Liu XL, Liu YP, et al. Di (2-ethylhexyl)phthalate impairs steroidogenesis in ovarian follicular cells of prepuberal mice. Arch Toxicol (2016). doi:10.1007/s00204-016-1790-Z

121. Hannon PR, Brannick KE, Wang W, Flaws JA. Mono(2-ethylhexyl)phthalate accelerates early folliculogenesis and inhibits steroidogenesis in cultured mouse whole ovaries and antral follicles. Biol Reprod (2015) 92(5):120. doi:10.1095/biolreprod.115.129148

122. Kovanecz I, Gelfand R, Masouminia M, Gharib S, Segura D, Vernet D, et al. Oral bisphenol A (BPA) given to rats at moderate doses is associated with erectile dysfunction, cavernosal lipofibrosis and alterations of global gene transcription. Int J Impot Res (2014) 26(2):67-75. doi:10.1038/ ijir.2013.37

123. Cencioni C, Spallotta F, Martelli F, Valente S, Mai A, Zeiher AM, et al. Oxidative stress and epigenetic regulation in ageing and age-related diseases. Int J Mol Sci (2013) 14(9):17643-63. doi:10.3390/ijms140917643

124. Rajesh P, Sathish S, Srinivasan C, Selvaraj J, Balasubramanian K. Phthalate is associated with insulin resistance in adipose tissue of male rat: role of antioxidant vitamins. J Cell Biochem (2013) 114(3):558-69. doi:10.1002/ jcb. 24399

125. Tiwari D, Kamble J, Chilgunde S, Patil P, Maru G, Kawle D, et al. Clastogenic and mutagenic effects of bisphenol A: an endocrine disruptor. Mutat Res (2012) 743(1-2):83-90. doi:10.1016/j.mrgentox.2011.12.023

126. Denu RA, Hematti P. Effects of oxidative stress on mesenchymal stem cell biology. Oxid Med Cell Longev (2016) 2016:2989076. doi:10.1155/2016/ 2989076

127. Kizilay Mancini O, Shum-Tim D, Stochaj U, Correa JA, Colmegna I Age, atherosclerosis and type 2 diabetes reduce human mesenchymal stromal cell-mediated T-cell suppression. Stem Cell Res Ther (2015) 6:140. doi:10.1186/s13287-015-0127-9

128. Bustos ML, Huleihel L, Kapetanaki MG, Lino-Cardenas CL, Mroz L, Ellis BM, et al. Aging mesenchymal stem cells fail to protect because of impaired migration and antiinflammatory response. Am J Respir Crit Care Med (2014) 189(7):787-98. doi:10.1164/rccm.201306-1043OC

129. Gu Y, Li T, Ding Y, Sun L, Tu T, Zhu W, et al. Changes in mesenchymal stem cells following long-term culture in vitro. Mol Med Rep (2016) 13(6):5207-15. doi:10.3892/mmr.2016.5169

130. Baker NA, Karounos M, English V, Fang J, Wei Y, Stromberg A, et al. Coplanar polychlorinated biphenyls impair glucose homeostasis in lean C57BL/6 mice and mitigate beneficial effects of weight loss on glucose homeostasis in obese mice. Environ Health Perspect (2013) 121(1):105-10. doi:10.1289/ ehp. 1205421

131. Kidani T, Kamei S, Miyawaki J, Aizawa J, Sakayama K, Masuno H. Bisphenol A downregulates Akt signaling and inhibits adiponectin production and secretion in 3T3-L1 adipocytes. J Atheroscler Thromb (2010) 17(8):834-43. doi:10.5551/jat.4051

132. Valentino R, D’Esposito V, Passaretti F, Liotti A, Cabaro S, Longo M, et al. Bisphenol-A impairs insulin action and up-regulates inflammatory pathways in human subcutaneous adipocytes and 3T3-L1 cells. PLoS One (2013) 8(12):e82099. doi:10.1371/journal.pone.0082099 
133. Hugo ER, Brandebourg TD, Woo JG, Loftus J, Alexander JW, Ben-Jonathan N. Bisphenol A at environmentally relevant doses inhibits adiponectin release from human adipose tissue explants and adipocytes. Environ Health Perspect (2008) 116(12):1642-7. doi:10.1289/ehp.11537

134. Portigal CL, Cowell SP, Fedoruk MN, Butler CM, Rennie PS, Nelson CC. Polychlorinated biphenyls interfere with androgen-induced transcriptional activation and hormone binding. Toxicol Appl Pharmacol (2002) 179(3):185-94. doi:10.1006/taap.2002.9371

135. Pourgholaminejad A, Aghdami N, Baharvand H, Moazzeni SM. The effect of pro-inflammatory cytokines on immunophenotype, differentiation capacity and immunomodulatory functions of human mesenchymal stem cells. Cytokine (2016) 85:51-60. doi:10.1016/j.cyto.2016.06.003

136. Crop MJ, Baan CC, Korevaar SS, JNM IJ, Pescatori M, Stubbs AP, et al. Inflammatory conditions affect gene expression and function of human adipose tissue-derived mesenchymal stem cells. Clin Exp Immunol (2010) 162(3):474-86. doi:10.1111/j.1365-2249.2010.04256.x

137. Szabo E, Fajka-Boja R, Kriston-Pal E, Hornung A, Makra I, Kudlik G, et al. Licensing by inflammatory cytokines abolishes heterogeneity of immunosuppressive function of mesenchymal stem cell population. Stem Cells Dev (2015) 24(18):2171-80. doi:10.1089/scd.2014.0581

138. Li W, Ren G, Huang Y, Su J, Han Y, Li J, et al. Mesenchymal stem cells: a double-edged sword in regulating immune responses. Cell Death Differ (2012) 19(9):1505-13. doi:10.1038/cdd.2012.26

139. Li C, Li G, Liu M, Zhou T, Zhou H. Paracrine effect of inflammatory cytokine-activated bone marrow mesenchymal stem cells and its role in osteoblast function. J Biosci Bioeng (2016) 121(2):213-9. doi:10.1016/ j.jbiosc.2015.05.017

140. Croes M, Oner FC, Kruyt MC, Blokhuis TJ, Bastian O, Dhert WJ, et al. Proinflammatory mediators enhance the osteogenesis of human mesenchymal stem cells after lineage commitment. PLoS One (2015) 10(7):e0132781. doi:10.1371/journal.pone.0132781

141. Sidney LE, Kirkham GR, Buttery LD. Comparison of osteogenic differentiation of embryonic stem cells and primary osteoblasts revealed by responses to IL-1beta, TNF-alpha, and IFN-gamma. Stem Cells Dev (2014) 23(6):605-17. doi: $10.1089 /$ scd.2013.0336

142. Liu C, Xiong H, Chen K, Huang Y, Huang Y, Yin X. Long-term exposure to pro-inflammatory cytokines inhibits the osteogenic/dentinogenic differentiation of stem cells from the apical papilla. Int Endod J (2016) 49(10):950-9. doi:10.1111/iej.12551

143. Wang YW, Xu DP, Liu Y, Zhang R, Lu L. The effect of tumor necrosis factor-alpha at different concentrations on osteogenetic differentiation of bone marrow mesenchymal stem cells. J Craniofac Surg (2015) 26(7):2081-5. doi:10.1097/SCS.0000000000001971
144. McLachlan JA. Environmental signaling: from environmental estrogens to endocrine-disrupting chemicals and beyond. Andrology (2016) 4(4):684-94. doi:10.1111/andr.12206

145. Yuan Z, Li Q, Luo S, Liu Z, Luo D, Zhang B, et al. PPARgamma and Wnt signaling in adipogenic and osteogenic differentiation of mesenchymal stem cells. Curr Stem Cell Res Ther (2016) 11(3):216-25. doi:10.2174/ 1574888X10666150519093429

146. Cruz G, Foster W, Paredes A, Yi KD, Uzumcu M. Long-term effects of early-life exposure to environmental oestrogens on ovarian function: role of epigenetics. J Neuroendocrinol (2014) 26(9):613-24. doi:10.1111/ jne.12181

147. De Felice B, Manfellotto F, Palumbo A, Troisi J, Zullo F, Di Carlo C, et al. Genome-wide microRNA expression profiling in placentas from pregnant women exposed to BPA. BMC Med Genomics (2015) 8:56. doi:10.1186/ s12920-015-0131-z

148. Turinetto V, Vitale E, Giachino C. Senescence in human mesenchymal stem cells: functional changes and implications in stem cell-based therapy. Int J Mol Sci (2016) 17(7):E1164. doi:10.3390/ijms17071164

149. Gimble JM, Katz AJ, Bunnell BA. Adipose-derived stem cells for regenerative medicine. Circ Res (2007) 100(9):1249-60. doi:10.1161/ 01.RES.0000265074.83288.09

150. Chiellini C, Cochet O, Negroni L, Samson M, Poggi M, Ailhaud G, et al. Characterization of human mesenchymal stem cell secretome at early steps of adipocyte and osteoblast differentiation. BMC Mol Biol (2008) 9(1):26. doi:10.1186/1471-2199-9-26

151. Li H, Fu X. Mechanisms of action of mesenchymal stem cells in cutaneous wound repair and regeneration. Cell Tissue Res (2012) 348(3):371-7. doi:10.1007/s00441-012-1393-9

152. Sorrell J, Caplan AI. Topical delivery of mesenchymal stem cells and their function in wounds. Stem Cell Res Ther (2010) 1(4):1-6. doi:10.1186/ scrt30

Conflict of Interest Statement: The authors declare that the research was conducted in the absence of any commercial or financial relationships that could be construed as a potential conflict of interest.

Copyright (c) 2017 Bateman, Strong, McLachlan, Burow and Bunnell. This is an open-access article distributed under the terms of the Creative Commons Attribution License (CC BY). The use, distribution or reproduction in other forums is permitted, provided the original author(s) or licensor are credited and that the original publication in this journal is cited, in accordance with accepted academic practice. No use, distribution or reproduction is permitted which does not comply with these terms. 